\title{
Harvest Residue Study of Fungicide Tebuconazole EC Formulation in Groundnut and Paddy
}

\author{
Chiranjit Kundu, Arnab Goon, Anjan Bhattacharyya
}

Pesticide Residue Laboratory, Department of Agricultural Chemicals, West Bengal, India.

Email: chirukundu@gmail.com

Received November $10^{\text {th }}, 2010$; revised February $7^{\text {th }}, 2011$; accepted March $12^{\text {th }}, 2011$.

\begin{abstract}
A field trial was conducted under West Bengal condition during July 2009 to October 2009 to evaluate the harvest residue of Tebuconazole $\left(25.9 \%\right.$ EC) in paddy at two application rates ( 750 and $1500 \mathrm{~mL} \cdot \mathrm{ha}^{-1}$ ). Another field trial was conducted during August 2009 to December 2009 to evaluate the harvest residue of the same molecule in groundnut. The quantitative analysis of the fungicide residue was performed using Liquid Chromatography-Mass Spectrometry (LC-MS/M S). The average recovery was found in between $86.33 \%$ to $91.87 \%$ for different substrates of groundnut. In case of paddy the average recovery was ranges in between $86.40 \%$ to $90.86 \%$ for different substrates. In all the cases, it was found that the fungicide residues were below the detection limit of the instrument $(<0.01 \mathrm{ppm})$ irrespective of doses in different substrates of paddy and groundnut. Based on these findings, the use of Tebuconazole in paddy and groundnut may be advocated for the control of diseases in paddy and groundnut without any residual toxicity problem.
\end{abstract}

Keywords: Control, Fungicides, Pyricularia Oryzae, Rice Blast, Oryza Sativa L

\section{Introduction}

Rice (Oryza sativa), one of the three most important food crops in the world, forms the staple diet for 2.7 billion people [1]. It is grown in all the continents except Antarctica, occupying 150 million ha, producing 573 million tonnes paddy with an average productivity of 3.83 tonnes $\cdot h^{-1}{ }^{-1}$ [2]. More than $70 \%$ grain loss may occur in India as a result of rice blast disease caused by fungus Pyricularia oryzae [3].

Similarly groundnut is one of the most important oilseed crop grown in wide range of soil and climate. Leaf spot is one of the most important diseases of groundnut caused by fungus Sclerotium rolfsii, causes significant yield losses under Indian climatic condition [4].

Tebuconazole [IUPAC Name: (RS)-1-(4-chlorophenyl)-4,4-dimethyl-3-(1H-1,2,4-triazol-1-ylmethyl)-pe ntan-3-ol. Ratio (1:1)], a triazole fungicide used as a seed dressing chemical is a systemic fungicide with protective, curative and eradicant action and acts by inhibiting the demethylation of steroids. Used as a spray, it controls numerous pathogens in various crops out of which leaf spot of groundnut, blast disease of paddy are major one [4]. Tebuconazole when applied in the form of fungicide accumulated in surface layers of soil and became toxic to susceptible plants. Also it is rapidly absorbed by vegetative parts of the plants with translocation principally acropetally. The objective of the present work was to study the harvest residue of Tebuconazole EC formulation in groundnut and paddy.

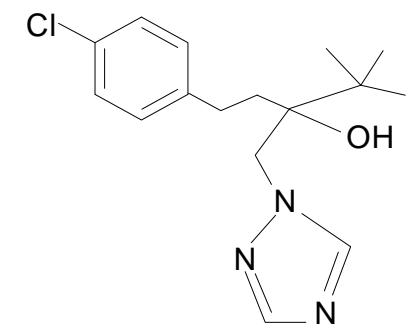

Chemical structure of Tebuconazole.

\section{Materials and Methods}

A field study was conducted at University Experimental Field, Mohanpur, BCKV, West Bengal, India, during July 2009 to October 2009 on paddy [variety-Khitish]. Another field study was conducted at University Experimental field, Gayeshpur, BCKV, West Bengal, India, during August 2009 to December 2009 on groundnut [variety-JL-24]. The formulation Tebuconazole $25.9 \%$ EC was applied with the help of knapsack 
sprayer equipped with WFN 40 nozzle@ $750 \mathrm{~mL} \cdot \mathrm{ha}^{-1}$ $\left(\mathrm{T}_{1}\right)$ and @1500 mL.ha ${ }^{-1}\left(\mathrm{~T}_{2}\right)$ in Randomized Block Designed (RBD) plots and maintained untreated control $\left(\mathrm{T}_{3}\right)$ plots. Three replications were used for each treatment. The area of every plot was $20 \mathrm{~m}^{2}$. Spraying of fungicide was done twice at 15 days interval both for paddy and groundnut.

\subsection{Collection of Samples and Processing}

Different substrates of groundnut (groundnut cropped soil, groundnut plant and groundnut) were collected at the time of harvest following standard sampling procedures. Also different substrates of paddy (paddy plant and paddy cropped soil) were collected at the time of harvest following the same procedure. Groundnut plant, paddy plant, groundnut $(0.10 \mathrm{~kg})$ and field soil $(0.25 \mathrm{~kg})$ samples were collected from 5 - 7 places randomly from each treatment plots. Samples from untreated control plots were also collected in the same way. Soil samples were collected from a depth of 6" with the help of soil auger.

\section{Residue Analysis}

\subsection{Extraction and Clean Up of Samples}

Plant samples (Paddy straw/Paddy grain/Husk/Groundnut plant):

The samples were blended using Polytron homogenizer. In each case five gram ( $5 \mathrm{~g})$ of the homogenized sample was taken in a $50 \mathrm{~mL}$ centrifuge tube and $10 \mathrm{~mL}$ (Ethyl Acetate: Cyclohexane $=9: 1$ ) mixture was added and subjected to vortex for $2 \mathrm{~min}$. After that added $5 \mathrm{gm}$ of activated $\mathrm{Na}_{2} \mathrm{SO}_{4}$, the sample was again vortex for $3 \mathrm{~min}$. Then the sample was centrifuged for $15 \mathrm{~min}$ at $10,000 \mathrm{rpm}$ and then $5 \mathrm{ml}$ supernatant liquid was taken in $10 \mathrm{ml}$ centrifuge tube. Afterwards $25 \mathrm{mg}$ florisil \& $25 \mathrm{mg}$ PSA was added to it and vortex for $2 \mathrm{~min}$ and the sample was again centrifuged for $10 \mathrm{~min}$ at $5000 \mathrm{rpm}$. Then $3 \mathrm{ml}$ supernatant liquid was collected from it and evaporated to dryness in a $\mathrm{N}_{2}-$ Evaporator at $25^{\circ} \mathrm{C}$. The residue was then reconstituted in $3 \mathrm{ml}$ of [ $\mathrm{MeOH}: \mathrm{H}_{2} \mathrm{O}(9: 1, \mathrm{v} / \mathrm{v})+5 \mathrm{mM}$ $\left.\mathrm{CH}_{3} \mathrm{COONH}_{4}\right]$ and subsequently filtered through $0.2 \mu$ membrane filter. Now the sample is ready for the final analysis with LC-MS/MS.

\section{Groundnut Oil:}

Deshelled groundnut sample (50 g) was grinded in a grinder and was subjected to Soxhlet extraction with 150 $\mathrm{mL}$ of hexane for 6 hours. The extracted oil was collected and the rest portion (deoil cake) was kept separately. The hexane extract was concentrated in rotary vacuum evaporator below $40^{\circ} \mathrm{C}$. The oil thus obtained was collected and from it $1 \mathrm{~g}$ of oil was weighed and was subjected to extraction. The oil taken was redissolved in
$100 \mathrm{~mL}$ of hexane and was partitioned thrice $(100+50+$ 50) with acetonitrile. The acetonitrile fraction was collected over anhydrous $\mathrm{Na}_{2} \mathrm{SO}_{4}$ and the organic phase was evaporated in a rotary vacuum evaporator below $40^{\circ} \mathrm{C}$ and was subjected to column clean up. The oil sample thus obtained was cleaned up using silica gel column conditioned with hexane. The sample was applied in the column and kept for $15 \mathrm{~min}$. It was then eluted with $50 \mathrm{~mL}$ hexane and discarded. Then $100 \mathrm{~mL}$ toluene was passed through the column and the fraction was collected and concentrated in a rotary vacuum evaporator below $40^{\circ} \mathrm{C}$. Finally, it was reconstituted with [MeOH: $\left.\mathrm{H}_{2} \mathrm{O}(9: 1, \mathrm{v} / \mathrm{v})+5 \mathrm{mM} \mathrm{CH}_{3} \mathrm{COONH}_{4}\right]$ which is ready for analysis in LC-MS/MS.

\section{Groundnut Deoil cake:}

The deoil cake (10 g) obtained from the oil extraction step was analysed by following same procedure as described for groundnut plant samples.

Soil (Both paddy and groundnut cropped soil):

Five gram $(5 \mathrm{~g})$ soil was taken in a $50 \mathrm{~mL}$ centrifuge tube \& similar method as mentioned in plant samples was followed.

\section{Instrumentatal Parameters:}

Chromatographic condition.

\begin{tabular}{|c|c|}
\hline Column & Waters Symmetry C-18, $5 \mu \mathrm{m}, 2.1 \times 100 \mathrm{~mm}$ \\
\hline Eluent & $\begin{array}{lllllll}\text { A: } \quad 5 \% \quad\left\{\mathrm{CH}_{3} \mathrm{OH}:\right. & \mathrm{H}_{2} \mathrm{O} & (1: 9) & + & 5 & \mathrm{mM} \\
\left.\mathrm{CH}_{3} \mathrm{COONH} \mathrm{NON}_{4}\right\} & & & & & \\
\text { B: } \quad 95 \% \quad\left\{\mathrm{CH}_{3} \mathrm{OH}:\right. & \mathrm{H}_{2} \mathrm{O} & (9: 1) & + & 5 & \mathrm{mM} \\
\mathrm{CH}_{3} \mathrm{COONH} & \end{array}$ \\
\hline Elution & Isocratic (Binary Solvent) \\
\hline Flow rate & $0.2 \mathrm{ml} / \mathrm{min}$ \\
\hline Stop time & $5 \mathrm{~min}$ \\
\hline Post time & $5 \mathrm{~min}$ \\
\hline Injection volume & $5 \mu 1$ \\
\hline Column temp. & $25^{\circ} \mathrm{C} \pm 0.8^{\circ} \mathrm{C}$ \\
\hline
\end{tabular}

Mass Spectrometric condition.

\begin{tabular}{ll}
\hline Instrument & Micromass Quattro micro API \\
\hline Ionization mode & ESCi multi-mode \\
Scan type & MRM \\
Capillary voltage $(\mathrm{kV})$ & $1.00 \mathrm{kV}$ \\
Cone voltage $(\mathrm{V})$ & $35 \mathrm{~V}$ \\
Extractor $(\mathrm{V})$ & $2 \mathrm{~V}$ \\
Source temperature & $120^{\circ} \mathrm{C}$ \\
Desolvation temperature & $350^{\circ} \mathrm{C}$ \\
Desolvation gas flow & $650.0(\mathrm{~L} / \mathrm{hr})$ \\
Cone $(\mathrm{L} / \mathrm{hr})$ & $25.0(\mathrm{~L} / \mathrm{hr})$ \\
Molecular ion & $308.14 \mathrm{amu}$ (used for quantation) \\
& $308.14 \rightarrow 69.6 \mathrm{amu}$ (for qualitative \\
& confirmation) \\
Mass transition & $308.14 \rightarrow 125.1 \mathrm{amu}$ (for qualitative \\
& confirmation) \\
& $308.14 \rightarrow 150.9 \mathrm{amu}$ (for qualitative \\
LOD & confirmation) \\
LOQ & $0.005 \mathrm{ppm}$. or $0.005 \mu \mathrm{g} / \mathrm{mL}$ \\
& $0.01 \mathrm{ppm}$. or $0.01 \mu \mathrm{g} / \mathrm{mL}$ (For all \\
\hline
\end{tabular}




\subsection{Linearity Check}

A calibration curve (Figure 1) was made by plotting seven concentrations $(0.01-1.00 \mu \mathrm{g} / \mathrm{g})$ of standard Tebuconazole versus absorption. Also, to know the interference of each substrate, matrix match calibration standard for each substrate was prepared. In this study calibration curve was prepared by taking the areas corresponding to different concentrations of matrix match calibration standard, against which final quantification was done.

\subsection{Recovery Test}

Recovery studies were carried out in order to establish the reliability of the analytical method and to know the efficiency of extraction and clean up steps employed for the present study, by fortifying the samples with different levels of analytical standard solution of Tebuconazole. It was carried out by fortifying different substrates of paddy and groundnut samples at the level of $0.01,0.10$ and $0.50 \mathrm{ppm}$ with the analytical standard solution of Tebuconazole and was analyzed following the procedure. Results of recovery study are shown in Table 1 and Table 2.

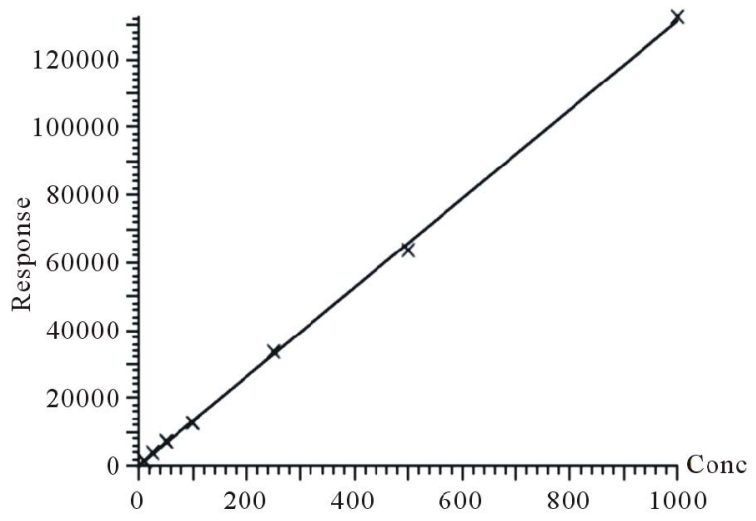

Figure 1. Calibration curve of analytical standard of Tebuconazole.

Table 1. Recovery study of Tebuconazole in different substrates of groundnut.

\begin{tabular}{lcccc}
\hline Substrate & $\begin{array}{l}\text { Amount } \\
\text { fortified } \\
\text { (ppm) }\end{array}$ & $\begin{array}{l}\text { Amount } \\
\text { recovered* } \\
\text { (ppm) }\end{array}$ & \% Recovery & $\begin{array}{l}\text { Average \% } \\
\text { recovery }\end{array}$ \\
\hline Field Soil & 0.01 & 0.009 & 90.00 & \\
& 0.10 & 0.089 & 89.00 & 91.87 \\
Groundnut & 0.50 & 0.483 & 96.60 & \\
Plant & 0.01 & 0.008 & 80.00 & 86.33 \\
(Haulm) & 0.10 & 0.086 & 86.00 & \\
Oil & 0.50 & 0.465 & 93.00 & \\
& 0.01 & 0.009 & 90.00 & \\
Deoil Cake & 0.10 & 0.093 & 93.00 & 90.93 \\
& 0.50 & 0.449 & 89.80 & \\
\hline
\end{tabular}

*Average of three replicates.
Table 2. Recovery study of Tebuconazole in different substrates of paddy.

\begin{tabular}{lllll}
\hline Substrate & $\begin{array}{l}\text { Amount } \\
\text { fortified } \\
\text { (ppm) }\end{array}$ & $\begin{array}{l}\text { Amount } \\
\text { recovered } \\
\text { (ppm) }\end{array}$ & \% Recovery & $\begin{array}{l}\text { Average \% } \\
\text { recovery }\end{array}$ \\
\hline Paddy & 0.01 & 0.008 & 80.00 & \\
Straw & 0.10 & 0.086 & 86.00 & 86.40 \\
& 0.50 & 0.466 & 93.20 & \\
Paddy & 0.01 & 0.009 & 90.00 & \\
Grain & 0.10 & 0.093 & 93.00 & 90.86 \\
& 0.50 & 0.448 & 89.60 & \\
Husk & 0.01 & 0.009 & 90.00 & \\
& 0.10 & 0.087 & 87.00 & 89.46 \\
& 0.50 & 0.457 & 91.40 & \\
Field Soil & 0.01 & 0.008 & 80.00 & \\
& 0.10 & 0.091 & 91.00 & 88.53 \\
\hline
\end{tabular}

* Average of three replicates.

\section{Results and Discussion}

\subsection{Recovery Study}

The recovery percentage of Tebuconazole from different substrates of groundnut and paddy were presented in Table 1 \& Table 2 respectively. As the recovery percentage is quite high for all the substrates, hence the method can be adopted for harvest residue study of Tebuconazole in different substrate of paddy and groundnut.

\subsection{Residues of Tebuconazole in Harvest Samples}

All the data regarding residues of Tebuconazole in harvest substrate of paddy and groundnut have been presented in Table 3 and Table 4 respectively. In all the cases, it was found that the fungicide residues were below the detection limit of the instrument $(<0.01 \mathrm{ppm})$ irrespective of doses in different substrates of paddy and groundnut. Adiver et al. [5,6], stated that tebuconazole effectively control groundnut diseases with no residual toxicity problem. Tirmali et al. [7] in 2001 stated same trend in their evaluation study of some new fungicides against rice blast. Moorman et al. [8] also reported that, application of Tebuconazole does not possess any residual toxicity problem in soil under vegetable production. Sandra et al. [9] and Chuan et al. [10] also reported the effectiveness of Tebuconazole against fungal diseases of peppermint crops and apple respectively without possessing any residual toxicity problem. So, it might be stated that Tebuconazole may not pose any residual toxicity problem in paddy and groundnut. Similar observations were also reported earlier about the safety issue of Tebuconazole [11-16]. Based on these findings, the use of Tebuconazole $25.9 \%$ EC in paddy and ground- 
Table 3. Harvest residue of Tebuconazole in different substrates of paddy.

\begin{tabular}{|c|c|c|c|c|c|c|c|}
\hline \multirow[t]{2}{*}{ Chemical applied } & \multirow[t]{2}{*}{ Substrate (Harvest) } & \multirow[t]{2}{*}{ Treatment } & \multicolumn{4}{|c|}{ Residues in ppm. } & \multirow{2}{*}{ Dissipation (\%) } \\
\hline & & & $\mathbf{R}_{1}$ & $\mathbf{R}_{2}$ & $\mathbf{R}_{3}$ & Mean \pm S.D & \\
\hline \multirow{8}{*}{ Tebuconazole } & \multirow[t]{2}{*}{ Cropped Soil } & 1 & BDL & BDL & BDL & - & - \\
\hline & & $\mathrm{T}_{2}$ & BDL & BDL & BDL & - & - \\
\hline & \multirow{2}{*}{ Straw } & $\mathrm{T}_{1}$ & $\mathrm{BDL}$ & BDL & $\mathrm{BDL}$ & - & - \\
\hline & & $\mathrm{T}_{2}$ & BDL & BDL & $\mathrm{BDL}$ & - & - \\
\hline & \multirow{2}{*}{ Husk } & $\mathrm{T}_{1}$ & BDL & $\mathrm{BDL}$ & BDL & - & - \\
\hline & & $\mathrm{T}_{2}$ & BDL & BDL & BDL & - & - \\
\hline & \multirow{2}{*}{ Grain } & $\mathrm{T}_{1}$ & BDL & $\mathrm{BDL}$ & BDL & - & - \\
\hline & & $\mathrm{T}_{2}$ & BDL & $\mathrm{BDL}$ & BDL & - & - \\
\hline
\end{tabular}

BDL: Below detection limit $(<0.01 \mathrm{ppm})$.

Table 4. Harvest residue of Tebuconazole in different substrates of groundnut.

\begin{tabular}{|c|c|c|c|c|c|c|c|}
\hline \multirow[t]{2}{*}{ Chemical applied } & \multirow[t]{2}{*}{ Substrate (Harvest) } & \multirow[t]{2}{*}{ Treatment } & \multicolumn{4}{|c|}{ Residues in ppm. } & \multirow{2}{*}{ Dissipation (\%) } \\
\hline & & & $\mathbf{R}_{1}$ & $\mathbf{R}_{2}$ & $\mathbf{R}_{3}$ & Mean \pm S.D & \\
\hline \multirow{8}{*}{ Tebuconazole } & Cropped Soil & $1_{1}$ & BDL & BDL & BDL & - & - \\
\hline & & $\mathrm{T}_{2}$ & BDL & BDL & $\mathrm{BDL}$ & - & - \\
\hline & Groundnut & $\mathrm{T}_{1}$ & BDL & BDL & $\mathrm{BDL}$ & - & - \\
\hline & Plant & $\mathrm{T}_{2}$ & $\mathrm{BDL}$ & BDL & BDL & - & - \\
\hline & \multirow{2}{*}{ Oil } & $\mathrm{T}_{1}$ & $\mathrm{BDL}$ & BDL & $\mathrm{BDL}$ & - & - \\
\hline & & $\mathrm{T}_{2}$ & $\mathrm{BDL}$ & $\mathrm{BDL}$ & $\mathrm{BDL}$ & - & - \\
\hline & \multirow{2}{*}{ Deoil Cake } & $\mathrm{T}_{1}$ & BDL & BDL & $\mathrm{BDL}$ & - & - \\
\hline & & $\mathrm{T}_{2}$ & BDL & BDL & BDL & - & - \\
\hline
\end{tabular}

BDL: Below detection limit $(<0.01 \mathrm{ppm})$.

nut in West Bengal may be advocated for the control of fungal diseases in paddy and groundnut.

\section{REFERENCES}

[1] FAOSTAT, "FAO Statistical Database", 2007. http://www.fao.org

[2] Indian Council of Agricultural research, "Hand Book of Agriculture, Pesticide residues," 5th Edition, New Delhi, 2007, pp. 553-587.

[3] H. N. Swamy, S. Sannaulla and M. D. Kumar, "Evaluation of New Fungicides against Rice Blast in Cauvery Delta," Karnataka Journal of Agricultural Sciences, Vol. 22, No. 2, 2009, pp. 450-451.

[4] R. Angelini, "Folicur (Tebuconazole): A New Triazole Fungicide With A Wide Spectrum Of Activity," Informatore-Agrario-Supplemento, Vol. 52, No. 15, 1996, pp. 46-50.

[5] S. S. Adiver, K. H. Anahosur and K. Giriraj, "Triazoles for Control of Foliar Diseases of Groundnut (Arachis Hypogaea L.)," Karnataka Journal of Agricultural Sciences, Vol. 8, No. 1, 1995, pp. 65-68.

[6] S. S. Adiver and K. H. Anahosur, "Efficacy of Some Triazole Fungicides Against Late Leaf Spot of Groundnut and Their Subsequent Effects on Sclerotium Rolfsii," Indian Phytopathology, Vol. 48, No. 4, 1995, pp. 459-462.

[7] A. M. Tirmali, S. B. Latake and N. J. Bendra, "Evaluation of New Fungicides for Control of Blast Disease of Rice," Journal of Maharashtra Agriculture University, Vol. 26, 2001, pp. 197-198.

[8] T. B. Moorman, "A Review of Pesticidal Effect in Soil Under Vegetable Production," Journal of Production and Agriculture, Vol. 2, 1989, pp. 14-23.

[9] M. Sandra, Robert C. Menary and Noel W. Davies, "Dissipation of Propiconazole and Tebuconazole in Peppermint Crops," Journal of Agricultural and Food Chemistry, Vol. 47, No. 1, 1999, pp. 294-298. doi:10.1021/jf980120e 
[10] L. Chuan, "Determination of Tebuconazole Residue in Soil and Apple," Journal of Anhui Agricultural Sciences, Vol. 37, No. 6, 2009, pp. 135-139.

[11] European Food Safety Authority, "Modification of The Existing Mrls For Tebuconazole in Mandarins and Passion Fruit," European Food Safety Authority Journal, Vol. 7, No. 10, 2009, pp. 1368.

[12] Food and Drug Administration of the United States, "Pesticide tolerances", 2003. http://www.cfsan.fda.gov

[13] M. A. Kastanias, S. Coward, A. Philippoussis and P. Diamantopoulou, "Residue Evaluation of the Azole Fungicides Prochloraz and Tebuconazole in the White Mushroom Agaricus Bisporus," Bulletin of Environmental Contamination and Toxicology, Vol. 77, No. 1, 2006, pp.
149-154. doi:10.1007/s00128-006-1044-5

[14] K. D. Srivastava, D. V. Singh, R. Aggarwal, A. K. Dixit and P. Bahadur, "Bioefficacy and Persistence of Tebuconazole against Loose Smut in Wheat," Indian Phytopathology, Vol. 50, No. 3, 1997, pp. 434-436.

[15] D. Shitienberg, "Integrated Management of Early and Late Blights of Potatoes in Israel," African Crop Science Journal, Vol. 9, No. 1, 2001, pp. 203-207.

[16] S. Mohapatra, A. Ahuja, G. K. Jagadish, G.S. Prakash and S. Kumar, "Behaviour of Trifloxystrobin and Tebuconazole on Grapes under Semi-Arid Tropical Climatic Condition," Pest Management Sciences, Vol. 66, No. 8, 2010, pp. $910-915$. 